\title{
Frozen Cartoon Film as a Learning Media to Improve the students' Pronunciation Ability
}

\author{
Shilvyna Rahma \\ English Education Program, Universitas Islam Nahdlatul Ulama Jepara Indonesia, e-mail \\ lovelyshilvyna@gmail.com \\ Husni Mubarok \\ English Education Program, Universitas Islam Nahdlatul Ulama Jepara Indonesia, e-mail \\ husni@unisnu.ac.id
}

\begin{abstract}
Pronunciation is an important factor in measuring achievement in learning speaking in English. Proof of speaking fluency by the students is shown when they communicate verbally with a native speaker. This study aims to explain the use of the Frozen cartoon film as a learning medium to improve the students' pronunciation ability. The research focuses are the Frozen 1 cartoon synopsis, the stages, and procedures for implementing the dubbing and subtitling method and screening the film using the dubbing method. This study uses a descriptive research method with a qualitative approach. Data collection was carried out by library research (library research). Sources of data in the form of written materials consist of primary data sources and secondary data sources. The validity of the data test emphasizes the validity and reliability test. The results of the study were analyzed using the content analysis method. The results showed that the cartoon "Frozen" as a learning medium was very appropriate to be practiced in improving the students' pronunciation skills. This media provides several benefits: (a) being a solution in communicating English orally, (b) providing interesting, attractive teaching media, and (c) choosing the right learning method so that it is effective for the students. The presentation of the "frozen" cartoon is packaged with interesting storyline pictures and audio sound that makes the students involved in the film. The dubbing and subtitling methods are learning methods to motivate the students to communicate in English. Effective and efficient media and methods can help the students engage in learning English and at the same time be motivated to communicate in English.
\end{abstract}

Keywords: cartoon film, learning media, pronunciation

\section{A. Introduction}

Choosing the right learning media can help achieve optimal language learning. The use of media in learning can help children in providing meaningful experiences for children. The use of media in learning can make it easier for the children to understand something abstract to be more concrete (Haryanto \& Mubarok, 2020). Sanjaya (2010) states that there are 3 types of media based on their nature, namely auditive, visual, and audio-visual media. Of these three types of media, audiovisual media is a very solutive medium to engage the students in learning English, so this requires a combination of both media factors (auditive and visual media). This is following the statement that audiovisual media is a better and more interesting medium because auditive media and visual media contain sound and photo elements such as video recordings, sound slides, and films (Mina \& Putranti, 2015).

The concentration that is used more often is using films where the students prefer cartoons. Cartoon films are interesting audio-visual-based media for children. Not only in terms of 
entertainment, but cartoon films can also be a learning facility in terms of vocabulary, expression accuracy, and main pronunciation. The advantages of cartoon films in attracting children's attention will make it easier for teachers to reach the main goal in sharing lessons on pronunciation (Ulfa, 2018).

In this era, the production of cartoon films is increasingly varied and the quality is increasing, one of which is currently popular is Frozen. Frozen is one of the cartoon films produced by Walt Disney. The film, which was first screened on November 29, 2013, in the United States, has gained a lot of advantages and achievements. Popularity, interesting plot, and clarity of pronunciation (including American Style) are the basic reasons for using the Frozen cartoon film in this research (Nugrahani, \& Fitria, 2013).

Dubbing is a method of imitating the voices of characters in films. This can attract the students' interest to communicate in English. While subtitling is a method of transcribing the film's dialogue that is displayed on the bottom screen. Both can help the students understand the correct pronunciation based on the movies they watch (Putri, Samad, \& Nasir, 2017).

Among the four language skills, speaking seems to be the most important communication skill for several reasons. First, speaking leads to an increase in language mastery. Swain (2005) claims that "the act of producing language (speaking or writing) is, under certain circumstances, part of the process of learning a second language". Second, many language learners consider speaking ability as a measure of language acquisition. They define fluency as the ability to communicate with others, more than the ability to read, write, or understand spoken language. For them, speaking is the most important skill to master. Third, language teaching research and conferences have long focused on speaking teaching approaches and methods. Fourth, a large number of conversations and other speaking course materials and media, both in print and online, are published non-stop.

According to Fraser (2000), the ability to speak English involves certain language elements, systems, and sub-skills such as vocabulary, grammar, and pragmatics. However, the most important of these is pronunciation. A person with good English pronunciation is likely to be understood even if he has a limited vocabulary or makes grammatical errors, whereas someone with poor English pronunciation will not be able to be understood, even if his grammar is perfect. Pardede (2010) stated that good pronunciation is closely related to clear oral communication. In terms of oral communication, people are judged by the way they speak, so a person with poor pronunciation can be judged as incompetent, uneducated, or lacking in knowledge. Since pronunciation is so important, it should be one of the first things learned in English. A person can live without an advanced vocabulary because he can use simple words to say what he wants to say. He can also live without advanced grammar because he can use simple grammatical structures instead. However, there is no such thing as "simple pronunciation".

Although very important, pronunciation is generally neglected in ESL and knowledge, lack of institutional resources, lack of suitable pronunciation materials, fear of producing the wrong English words, lack of training, lack of time, and lack of motivation and confidence, EFL teachers do not like teach English pronunciation in their classrooms (Gilakjani \& Sabour, 2016). This omission in pronunciation will certainly lead the students to face many problems and will find it difficult to understand native English speakers and vice versa can be understood by their audience.

Henning, Weidner \& Marty (2008) explain that pronunciation is the most important thing in the process of learning English, so it requires more attention from various parties. Pronunciation is an important factor in measuring achievement in learning speaking in English. Proof of speaking fluency by the students is shown when they communicate verbally with a native speaker (Yudar, Aditomo \& 
Silalahi, 2020). Educators and parents are the main support system for the success of the students' pronunciation in English (Juliana, 2018).

Important aspects of pronunciation consist of fluency of spelling and pronunciation, the accuracy of spelling pronunciation, stressing, and intonation. The selection of interesting media in learning pronunciation can stimulate the students to pronounce vowels, consonants, and diphthongs correctly with stressing and correct intonation.

Several previous studies, such as Seferoğlu (2008), Florence (2009), and Ismaili (2013) show that film as a teaching medium has also been found to be an effective motivator for learning pronunciation. A film is a series of still or moving images. These are produced by recording photographic images with a camera, or by creating images using animation techniques or visual effects. Nasution (2005, p. 104) states that "every student can learn something from films, from the smart or the less intelligent". They can learn about the language style, culture, and expressions of native speakers. So that they can improve their English pronunciation more easily. Media such as movies can motivate the students to learn pronunciation and make the teaching atmosphere different from what they usually get in class.

Subsequent research was conducted by Pratiwi (2010) who reported that "English films influence the students to understand the pronunciation." Before the students watch English films, the students experience some difficulties with English stress patterns. After they watched English films, they were very good at English stress patterns. Kalean (2013, p. 155) points out that "teaching English using English films as a medium in EFL classes is a good way to teach the students how to speak well by imitating actors and actresses in films." The students can listen to how to link their words together. In addition, Deny's research (2012) revealed that films can improve the students' pronunciation skills. This is supported by the findings that: (a) the students made fewer errors in producing certain sounds; (b) they make fewer mistakes in reading dialogue using English stress patterns, and (c) they can produce up and down intonation.

Based on the writer's observation, the seventh-grade the students at SMPN 2 Pecangaan Jepara have quite a lot of problems with English pronunciation. The majority of them tend to ignore many aspects of pronunciation when speaking, including voice intonation, rhythm, pauses, and links from them not distinguishing between the pronunciation of love and deer or see and he. They also don't use a different intonation for Can you see Ali? And can you see, Ali? As a result, their speech is difficult to understand. Based on the responses of the English teacher and some the students, it is mainly since pronunciation is completely ignored in their English class.

Paying attention to this, the students should have media that can support these achievements, such as watching frozen cartoons as learning media. So, the frozen cartoon was chosen as a learning medium with a test system where the students are required to say some words with the right pronunciation in a cartoon dialogue. This media can improve the students' pronunciation skills.

This study aims to explain the use of the Frozen cartoon film as a learning medium to improve the students' pronunciation ability. The research focuses on the Frozen 1 cartoon synopsis, the stages, and procedures for implementing the dubbing and subtitling method, and screening the film using the dubbing method. The implementation of this research has the hope that the students can apply the frozen cartoon films into direct practice activities so that their pronunciation can improve faster.

\section{B. Research Methodology}

This study uses descriptive research methods to describe phenomena in terms of forms, activities, characteristics, changes, relationships, similarities, and differences between phenomena. This research was conducted to obtain an in-depth picture of the object of research, namely the use of 
the Frozen cartoon film as a learning medium to improve the students' pronunciation skills (Strauss \& Corbin, 2003; Sugiyono, 2012). This research approach is qualitative with the stages of activities including determining problems, conducting literature studies, determining data collection methods, analyzing data during research, analyzing data after validation and reliability, and describing the results in a conceptual narrative. Researchers as a key instrument for its success (Creswell, 2003; Mulyadi, M. (2011).

In collecting data, library research is carried out by utilizing library sources, such as books, magazines, documents, records of historical stories Arifin, Z. (2020). Data collection techniques are carried out through several procedures, namely: (1) Determination of the unit of analysis, to obtain data relevant to the object of research; (2) Determination of the sample, by knowing the year of publication of a work, theme, genre, and so on (determination of stratified samples); (3) Data recording, by conducting data selection or data reduction to facilitate researchers in determining indicators (Endraswara, 2011:162-163).

Sources of data in the form of written materials consist of primary data sources and secondary data sources. Primary data sources are data obtained directly from research subjects in the form of books related to learning media. Secondary data sources are journals and other literature related to the title of this study (Darmadi, 2011).

The validity of the data in this study emphasizes the validity test on the degree of accuracy between the data in the research object and data that can be reported by researchers and reliability on the degree of consistency and stability of the data or findings (Sugiyono, 2009:363-364).

The results of the study were analyzed using the method of content analysis (content study). The researcher uses a content analysis model to discuss in depth the contents of written information (text content) or printed in the mass media. Content analysis also analyzes all forms of communication, both newspapers, radio news, television advertisements, and all other documentation materials to conclude efforts to find the characteristics of messages objectively and systematically. The content study is a research technique that is used to draw replicative and valid conclusions from data based on its context (Krippendorff) or find the characteristics of the message and is carried out objectively and systematically (Sugiyono, 2007:308; Ma'arif, 2011).

\section{Results}

\section{The Synopsis Cartoon "Frozen 1"}

This cartoon tells the story of two daughters of the kingdom of Arendelle. One of them named Elsa has the power of ice. When they were both young, an accident occurred. Elsa's ice powers accidentally injure her sister Anna while they are playing. Which then requires Elsa to hide her powers behind her gauntlets.

When the two of them grew up, Elsa and Anna's parents died on a ship in the vast ocean. Elsa as the first princess was appointed as the successor of the kingdom and the coronation was immediately held. At Elsa's coronation, a big event happened. Anna, who felt that she had found her true love, immediately said that she wanted to marry her sister. But Elsa does not agree and a conflict occurs. Her gauntlets fall off and her powers accidentally hurt Anna again and turn her kingdom into eternal winter.

Elsa runs and secludes herself in the icy mountains. Anna chased after her sister, namely to the north mountain. On the way, he met Kristoff the iceman with his deer. Then he met Olaf, the snowman he played with when he was little. From here the adventure of saving jobs begins.

At the end of the story, Anna slowly turns to ice because Elsa's power was the last time that hit her. He must immediately get the warmth of his true love before it turns into ice. But it turns out 
that the man she chose was a bad person. He even wanted to kill his brother for power. In the last seconds, Anna was completely frozen, she saved Elsa from aiming the sword. Elsa hugged her sister who then melted her. Realizing that it was his love and warmth that saved Anna. Elsa finally realizes that love is the key that can control her powers. Elsa was then able to return Arendelle as usual. Finally, Elsa can rule her kingdom with wisdom and joy.

The success of learning English pronunciation with frozen film fragments for the students is carried out through learning evaluation. Evaluation is carried out in several stages.

\section{The Stages and Procedures for Implementation of the Dubbing and Subtitling Method}

Several stages or procedures for implementing the dubbing and subtitling method as a guide for the students' English conversation practice in research activities:

a. Stages of screening cartoon films with Indonesian subtitles (Indonesian subtitle version).

At this stage, the students are directed to watch the Frozen cartoon film and get the results. The students listen and watch the film looking carefully while paying attention to the Indonesian subtitled version of the Indonesian translation transcription). so that this activity can help the students understand the content and storyline in the film because it is presented through Indonesian transcription at the bottom of the screen. The following picture shows the students watching and watching films in research activities:

b. Stages of film screening with transcription in English (temperature titling version).

At this stage, the students are directed to watch and listen to the film titled Frozen carefully by applying the subtitle method by paying attention to the following instructions:

1) The students watch and listen to the Frozen movie carefully using the subtitling method

2) The students are taught the method of subtitling beforehand, by:

a) Paying attention to the English subtitles displayed at the bottom of the film (English subtitling version)

b) Distributing the worksheets of the vocabulary list along with meanings that must be considered for pronunciation to the students

Matching the use of vocabulary in the film's dialogue by discussing the use of vocabulary or expressions in the subtitles of the film's dialogue through a random guessing game of film dialogue (Frozen). For example in the following illustration. what dialogues do movie characters say?

\section{Discussion}

Based on the research result, general media interpretation, for example, film and other screen interpretation can be a confounded process (Remiere, 2010). Subtitling and naming are the most wellknown structures. A third choice, voice-over interpretation, includes at least one entertainer voices that are recorded over the first soundtrack, which can in any case be heard behind the scenes. Maybe stemming from the utilization of Benshi entertainers in Japan, who described and carried on discourse during the quiet film time, voice-over interpretation is utilized around the world for narrative and news content. For model, the conventional strategy for AVT in Poland is the utilization of a solitary lektor, a (normally male) voice-over entertainer who gives the interpretation of all characters' discourse, expressed over the film's soundtrack (Sepielak \& Matamala, 2014).

Captioning isn't just an interpretation between dialects yet additionally between methods of correspondence - from the expressed word to the composed word. Captioning additionally presents hardships in reality limitations that limit what amount can be said. Captioning regularly prohibits expressions or whole sentences and the most careful interpretation is much of the time disregarded for a more brief interpretation. There are equal issues in naming. The principle issue with naming is 
synchronization, where the interpretation is coordinated to the developments, both lip and signals, of the first visual work. Expressions are rephrased to coordinate with the developments better, however maybe not to all the more likely match the significance of the first (Chuang, 2006).

Other more subtle issues have likewise been contemplated. More often than not, an off-screen discourse isn't deciphered. Dastjerdi and Jazini (2011) contend that by not interpreting this material, the objective crowd hates the film as much as they would if this exchange were deciphered. The "realness" of the made an interpretation of exchange is raised doubt about, in both naming and captioning. Howell (2007) examines the distinctions between a few captioned forms of different Japanese anime films. The contrasts between the English captions accessible to the Japanese market and to the American market shift definitely in exchange. The forms accessible to the Japanese market use captions that are written in appropriate English that come up short to pass on something besides exchange. The English adaptations, done by well-known interpreters, utilize more casual phrasings, which assist with passing on character connections and foundations.

At the stage of film screening with dubbing method, the students are directed to watch and listen to the film entitled 'Frozen' carefully by applying the dubbing method by following the following instructions:

a. The students listen and watch the film Frozen carefully using the dubbing method

b. The students are taught the dubbing method in several ways as follows:

1) Paying attention and listening carefully to the pronunciation of vocabulary in the film dialogue (pronunciation) and the way Rogue film dialogue how to pronoun the word). At this stage, the students are instructed to remember the vocabulary of English film dialogue by applying imitating techniques, namely, the students are directed to practice speaking English skills by imitating the vocabulary spoken by the actors in the film.

The following is a sample dialogue used in learning activities:

Table 1 Sample dialogue used in learning activities

\begin{tabular}{|r|l|}
\hline No & \multicolumn{1}{|c|}{ Dialog } \\
\hline 1 & Anna, go back to sleep. \\
\hline 2 & Hi, I'm Olaf and I like warm hugs. \\
\hline 3 & Catch me! \\
\hline 4 & Please, help. My daughter! \\
\hline 5 & "Do You Want to Build a Snowman?" \\
\hline 6 & No. Don't touch me. I don't want to hurt you. \\
\hline 7 & That's not my fault. \\
\hline 8 & I bet they are beautiful. \\
\hline 9 & Your sister's coronation, ma'am. \\
\hline 10 & Your Majesty, the gloves. \\
\hline 11 & And what is that amazing smell? \\
\hline 12 & $\ldots$ Your physique helps I'm sure. \\
\hline 13 & Yeah, the whole thing! You got it. \\
\hline 14 & Fine. You can't marry a man you just met. \\
\hline 15 & The party is over. Close the gates. \\
\hline 16 & $\ldots$ And my sister's not a monster. \\
\hline 17 & North Mountain. \\
\hline 18 & Look, I know how to stop this winter. \\
\hline
\end{tabular}




\begin{tabular}{|r|l|}
\hline 19 & Who marries a man she just met? \\
\hline 20 & You're creepy \\
\hline 21 & No, I know we can figure this out together-- \\
\hline 22 & It is not nice to throw people! \\
\hline 23 & I'm digging a snow anchor. \\
\hline 24 & Kristoff, they sound wonderful. \\
\hline 25 & And I earned my fire crystal. \\
\hline
\end{tabular}

2) Presenting and explaining the knowledge of how to pronounce some important vocabulary in the film

3) Replaying some shows on how to pronounce vocabulary in film dialogues and train the students to pronounce film dialogue vocabulary.

c. The students are directed to practice speaking English skills by playing back original films without subtitles. In this case, the students practice film dialogue based on scenes with dubbing techniques, namely imitating conversational dialogues said by actors in the film. At this stage, the students act out film dialogue scenes by actors by imitating the voices made by actors. This dubbing method can be applied in the following ways:

1) Dubbing in English (Original) This English dubbing can train the students' English speaking skills. because the students are trained and directed to practice conversations in film dialogues by imitating the voices performed by actors using the original language of the film or in English.

2) Dubbing in Indonesian. Through dubbing behind the scene, it helps the students understand the story of the film as well as increases vocabulary and its meanings to help the students understand the art vocabulary as well as determine the right vocabulary to fill in the voices in the film.

Some of the instructions given to the students aim to increase the students' knowledge of pronunciation and how to pronounce English vocabulary as well as to train the students' speaking skills

Based on the data that has been obtained, it can be concluded that the students are very interested, enthusiastic, more confident in pronouncing English fluently and correctly according to the vocabulary in the "frozen" cartoon. The percentage reaches 90\%, the students whose English skills are still low can take part in this learning process. The last activity in performance can be seen very clearly the difference between participants who were not yet confident in pronouncing English vocabulary, now they are more confident and independent in communicating verbally with native speakers or meeting foreigners.

\section{E. Conclusion}

The researchers can describe the following conclusions: First, learning pronunciation with film media is an interesting learning process. Showing fragments of films that are adapted to theme of learning is more effective than showing the film as a whole. In part of the film, participants can immediately understand the conversation with a shorter duration of time, so that participants find it easy to record the language displayed. In the end, participants were able to retell the contents of the film fragments in good language. Second, there are three pieces of frozen film that we showed (An Act of True Love, Anything You Can Do, and Happy Ending). For each theme, participants get new 
language and vocabulary expressions, such as adjectives, nouns, and verbs as well as an introduction to grammar, namely comparative degree, and simple past tense. After gaining this new knowledge, participants rewrite what they have watched and then make a conversation script. Participants display their performance in pairs (pair work). The results of the participants' performance can be seen in video recordings.

\section{References}

Arifin, Z. (2020). Metodologi penelitian pendidikan. Jurnal Al-Hikmah, l(1).

Azwar, Darmadi, H..(2011). Metode Penelitian. Yogyakarta: Pustaka Pelajar

Chih-Pei, H. U., \& Chang, Y. Y. (2017). John W. Creswell, research design: Qualitative, quantitative, and mixed methods approaches. Journal of Social and Administrative Sciences, 4(2), 205-207.

Darmadi, Hartono. Azwar, S.(2011). Metode Penelitian. Yogyakarta: Pustaka Pelajar. Azwar, S.(2012). Penyusunan Skala Psikologi. Edisi 2. Yogyakarta: Pustaka Pelajar.

Dastjerdi, H. V., \& Jazini, A. (2011). Killing two birds with one stone: Translation of the unseen and off-camera speech and sounds in English movies subtitled into Persian. Journal of International Social Research, 4(19), 60-77.

Deny (2012). The effectiveness of teaching pronunciation through watching English movie. Surabaya

Endraswara, Suwardi. (2011). Metodologi Penelitian Sastra. Yogyakarta: Tim Redaksi CAPS

Florence, Y. (2009). Learning English through films: A case study of a Hong Kong class. University of Hong Kong.

Fraser, C. A. (1999). Lexical processing strategy use and vocabulary learning through reading. Studies in second language acquisition, 21(2), 225-241

Gilakjani, A. P., \& Sabouri, N. B. (2016). Learners' Listening Comprehension Difficulties in English Language Learning: A Literature Review. English language teaching, 9(6), 123-133.

Haryanto, H., \& Mubarok, H. (2020). Teacher's Directive Expressions Analysis in English Teaching Classes. Lensa: Kajian Kebahasaan, Kesusastraan, dan Budaya, 8(1), 22-42

Henning, J. M., Weidner, T. G., \& Marty, M. C. (2008). Peer assisted learning in clinical education: Literature review. Athletic Training Education Journal, 3(3), 84-90.

Howell, P. (2007). Character voice in anime subtitles. Perspectives, 14(4), 292-305.

Ismaili, M. (2013). The effectiveness of using movies in the EFL classroom: A study conducted at South East European University. Academic Journal of Interdisciplinary Studies, volume 2 (4), pp. 121-132. Retrieved from http://dx.doi.org/10.5901/ajis.2012.v2n4p121

Juliana, J. (2018). Motivasi Pembelajaran dan Percakapan Bahasa Inggris melalui Media Film dengan Metode Dubbing dan Subtitling. https://doi.org/10.31227/osf.io/tjmxu. . diunduh tanggal 25 Juli 2021.

Kalean, I. (2013). Speaking skill improvement by using movies as media. Educational Journal of Islamic University of Malang, 1(13), pp. 155-160. Retrieved from http://www.fkipunisma.ac.id/wp-content/uploads/2013/08/Imayati-Kalean_2013.pdf

Krippendorff, K. (2004). Content Analysis: An Introduction to its Methodology. New. York: Sage Publication

Mina, N., \& Putranti, S. D. (2015). Designing Cartoon as a Supplementary Material for English Structure Subject. Dinamika Ilmu, 15(1), 115-136. 
Mulyadi, M. (2011). Penelitian kuantitatif dan kualitatif serta pemikiran dasar menggabungkannya. Jurnal studi komunikasi dan media, 15(1), 128-137.

Ramière, N. (2010). Are you" lost in translation"(when watching a foreign film)? Towards an alternative approach to judging audiovisual translation. Australian Journal of French Studies, 47(1), 100-115.

Nasution. (2005). Teknologi pendidikan. Jakarta: Bumi Aksara.

Nugrahani, D., \& Fitria, F. (2013). The Use of Cartoon "Frozen Movie" as Visual Media to Improve the students' Ability in Learning Speaking: A Case of Ninth Grade The students of SMP Sultan Agung Semarang. ETERNAL (English Teaching Journal), 4(1).

Pardede, P. (2011). Using short stories to teach language skills. JET (Journal of English Teaching), 1(1), 14-27.

Pratiwi, M. (2010). Improving pronunciation ability using English cartoon films. (Undergraduate thesis of Sebelas Maret University). Retrieved July 25, 2021

Putri, C. I. D., Samad, I. A., \& Nasir, C. (2017). The Use of Cartoon Clips to Teach Listening Skill. Research in English and Education Journal, 2(3), 8-16.

Sanjaya, Wina. (2010). Strategi Pembelajaran Berorientasi Standar Proses Pendidikan. Jakarta: Kencana.

Seferoğlu, G. (2008). Using feature films in language classes. Educational Studies, pp. 1-9. Retrieved from http://dx.doi.org/10.1080/03055690701785202

Sepielak, K., \& Matamala, A. (2014). Synchrony in the voice-over of Polish fiction genres. Babel, 60(2), 145-163.

Setter, J. (2008). Theories and approaches in English pronunciation. R. Monroy \& A. Sanchez (Eds.), 25, 447-457.

Strauss, A., \& Corbin, J. (2003). Penelitian Kualitatif. Yogyakarta: Pustaka Pelajar.

Sugiyono, (2007). Metode Penelitian Kuantitatif, Kualitatif, dan R \& D. Bandung: Alfabeta

Sugiyono. (2009). Metode Penelitian Kuantitatif, Kualitatif dan R\&D. Bandung: Alfabeta

Sugiyono. (2012). Metode penelitian kuantitatif kualitatif dan R\&D. Bandung: Alfabeta

Swain, K. D. (2005). CBM with goal setting: Impacting the students' understanding of reading goals. Journal of Instructional Psychology, 32(3), 259.

Swain, M. (2005). The output hypothesis: Theory and research. In E. Hinkel (Ed.), Handbook of research in second language teaching and learning, pp. 471-483. Mahwah, NJ: Lawrence Erlbaum Associates, Inc.

Ulfa, F. (2018). Teaching vocabulary using cartoon movie. Journal of Languages and Language Teaching, 5(1), 23-27.

Yudar, R. S., Aditomo, D. T., \& Silalahi, N. S. (2020). Movie as a Helper for The students' Pronunciation in Speaking Skill Class. Elsya: Journal of English Language Studies, 2(1), 1519. 